\title{
GURU PROFESIONAL: Dalam Tugas Pokok dan Fungsi (Tupoksi)
}

\section{Syarifuddin}

STIT Al Amin Banten

syarifuddin80@gmail.com

\begin{abstract}
:
Teacher must become inspiration for his students in creativity and model aspects. Therefore teacher must have certain personal quality standard; it covers responsibility, authority, independence and discipline. The duties of teacher are: First, as a teacher (instructional) namely he plans teaching program and carries out the program and gives score after the program was carried out. Second, as educator namely he directs the students toward adulthood level that they have perfect personalities. Third, as leader (managerial) namely he leads and controls himself, students and related community or people about the effort of directing, controlling, organizing, and participating for the program.
\end{abstract}

Keywords: Teacher, Duty, Teaching. 


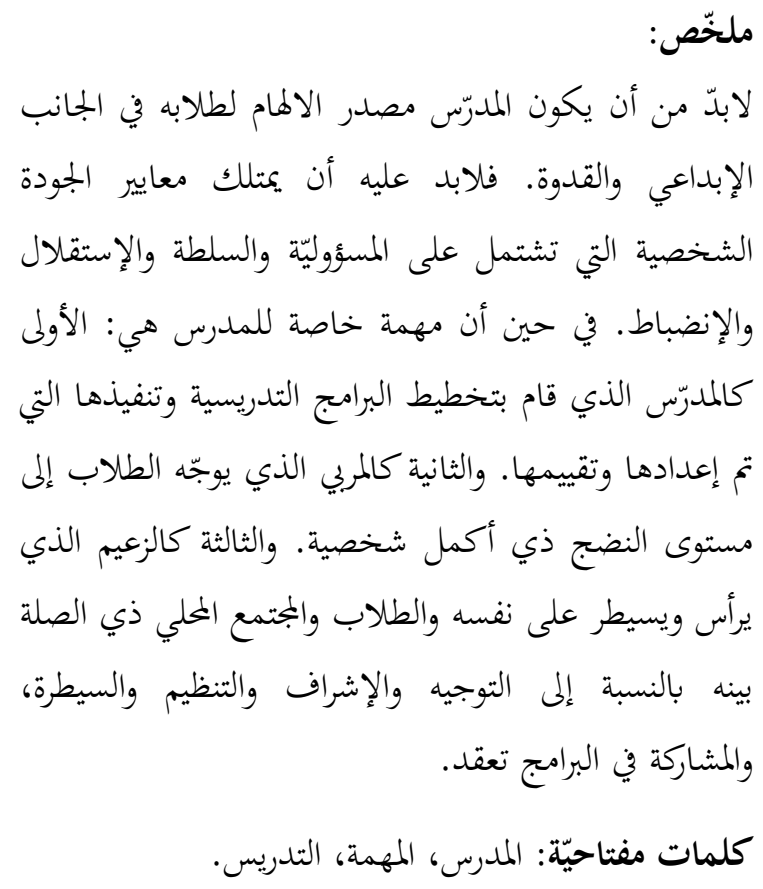

$\mathrm{K}$

aidah lama mengatakan jika guru kencing berdiri, murid kencing berlari. Sosok keteladanan yang melekat pada seorang guru menjadikan dirinya sebagai tolok ukur bagi pengembangan kepribadian, ketaatan, pola pikir, rujukan, dan tingkah laku siswa dalam bertindak. Guru yang baik adalah guru yang mampu menjadi inspirasi bagi muridnya, untuk dapat berkarya, menciptakan budaya positif, menggugah kreativitas, menumbuhkan kedewasaan, keteladanan bahkan menghantarkan siswa untuk dapat melampaui dirinya, dalam pengabdian terhadap agamanya, dirinya, keluarganya, masyarakat dan bangsanya sebagai bentuk penghambaan dirinya kepada Allah Swt.

Begitu besar dan agungnya tugas pokok dan fungsi seorang guru bagi muridnya, sehingga melahirkan catatan, pemikiran, rambu-rambu, kriteria guru profesional menurut para ahli pendidikan. Di sini penulis kutipkan sebagai bahan berdiskusi dan penambahan wawasan dalam telaah teoretik dan praktik dalam peran dan tugas sebagai seorang guru. 


\section{Syarifuddin}

\section{A. Peran Guru}

\section{Pendidik}

Mendidik dikenal sebagai tugas untuk memanusiakan manusia. Siswa adalah manusia yang belum menjadi manusia seutuhnya sehingga memerlukan bantuan orang dewasa. Melalui proses pembelajaran, segala sikap dan tingkah laku siswa ditingkatkan menjadi lebih baik sehingga terbentuk sebuah karakter yang baik.

Adanya kasus kenakalan remaja menyebabkan pihak guru menjadi salah satu pihak yang ikut mendapat tudingan di tengah masyarakat. Guru termasuk pihak yang bertanggung jawab terhadap sikap dan tingkah laku remaja menyimpang. Perkelahian massal antar pelajar sekolah, balapan liar di jalanan, dan sejumlah bentuk kenakalan remaja lainnya.

Guru adalah pendidik yang menjadi tokoh, panutan, dan identifikasi bagi peserta didik, dan lingkungannya. Oleh karena itu, guru harus memiliki standar kualitas pribadi tertentu, yang mencakup tanggung jawab, wibawa, mandiri dan disiplin.

\section{Pengajar}

Guru juga bertugas mengajar. Mengajar artinya mentransfer sejumlah ilmu pengetahuan kepada siswa. Mengajar bermakna untuk menyentuh ranah intelektual dan kecerdasan siswa. Untuk mengajar diperlukan berbagai strategi dan metode sehingga proses transfer ilmu pengetahuan kepada siswa menjadi lancar.

Pengertian 'mengajar' yang sesungguhnya adalah menciptakan situasi dan kondisi supaya siswa belajar. Guru dikatakan belum mengajar kalau siswa belum belajar. Jadi, orientasi proses pembelajaran di ruang kelas berorientasi kepada proses belajar siswa.

Kegiatan belajar peserta didik dipengaruhi oleh berbagai faktor, seperti motivasi, kematangan, hubungan peserta didik dengan guru, kemampuan verbal, tingkat kebebasan, rasa aman, dan keterampilan guru dalam berkomunikasi.

Jika faktor-faktor di atas dipenuhi, maka melalui pembelajaran peserta didik dapat belajar dengan baik. Oleh karena itu, guru harus berusaha membuat sesuatu menjadi jelas bagi peserta didik, dan berusaha lebih 


\section{GURU PROFESIONAL: Dalam Tugas Pokok dan Fungsi (Tupoksi)}

terampil dalam memecahkan masalah. Untuk itu, terdapat beberapa hal yang perlu dilakukan guru dalam pembelajaran diantaranya:

a. Membuat ilustrasi

b. Mendefinisikan

c. Menganalisis

d. Menyintesis

e. Bertanya

f. Merespons

g. Mendengarkan

h. Menciptakan kepercayaan

i. Memberikan pandangan yang bervariasi

j. Menyediakan media untuk mengkaji materi standar

k. Menyesuaikan materi pembelajaran

1. Memberikan nada perasaan

\section{Pembimbing}

Guru berusaha membimbing siswa agar dapat menemukan berbagai potensi yang dimilikinya, membimbing siswa agar dapat mencapai dan melaksanakan tugas-tugas perkembangan mereka, sehingga dengan ketercapaian itu ia dapat tumbuh dan berkembang sebagai individu yang mandiri dan produktif. Siswa adalah individu yang unik. Artinya, tidak ada dua individu yang sama. Walaupun secara fisik mungkin individu memiliki kemiripan, tetapi pada hakikatnya mereka tidaklah sama, baik dalam bakat, minat, kemampuan dan sebagainya. Di samping itu setiap individu juga adalah makhluk yang sedang berkembang. Irama perkembangan mereka tentu tidak sama juga. Perbedaan itulah yang menuntut guru harus berperan sebagai pembimbing.

Hubungan guru dan siswa seperti halnya seorang petani dengan tanamannya. Seorang petani tidak bisa memaksa agar tanamannya cepat berbuah dengan menarik batang atau daunnya. Tanaman itu akan berbuah manakala ia memiliki potensi untuk berbuah serta telah sampai pada waktunya untuk berbuah. Tugas seorang petani adalah menjaga agar tanaman itu tumbuh dengan sempurna, tidak terkena hama penyakit yang dapat menyebabkan tanaman tidak berkembang dan tidak tumbuh dengan sehat, yaitu dengan cara menyemai, menyiram, memberi pupuk dan memberi 


\section{Syarifuddin}

obat pembasmi hama. Demikian juga halnya dengan seorang guru. Guru tidak dapat memaksa agar siswanya jadi 'itu' atau jadi 'ini'. Siswa akan tumbuh dan berkembang menjadi seseorang sesuai dengan minat dan bakat yang dimilikinya. Tugas guru adalah menjaga, mengarahkan dan membimbing agar siswa tumbuh dan berkembang sesuai dengan potensi, minat dan bakatnya. Inilah makna peran sebagai pembimbing. Jadi, inti dari peran guru sebagai pembimbing adalah terletak pada kekuatan intensitas hubungan interpersonal antara guru dengan siswa yang dibimbingnya.

Lebih jauh, Abin Syamsuddin (2003) menyebutkan bahwa guru sebagai pembimbing dituntut untuk mampu mengidentifikasi siswa yang diduga mengalami kesulitan dalam belajar, melakukan diagnosa, prognosa, dan kalau masih dalam batas kewenangannya, harus membantu pemecahannya (remedial teaching). Berkenaan dengan upaya membantu mengatasi kesulitan atau masalah siswa, peran guru tentu berbeda dengan peran yang dijalankan oleh konselor profesional. Sofyan S. Willis (2004) mengemukakan tingkatan masalah siswa yang mungkin bisa dibimbing oleh guru, yaitu masalah yang termasuk kategori ringan, seperti: membolos, malas, kesulitan belajar pada bidang tertentu, berkelahi dengan teman sekolah, bertengkar, minum minuman keras tahap awal, berpacaran, mencuri kelas ringan.

Dalam konteks organisasi layanan bimbingan dan konseling, di sekolah, peran dan kontribusi guru sangat diharapkan guna kepentingan efektivitas dan efisien pelayanan bimbingan dan konseling di sekolah. Prayitno (2003) memerinci peran, tugas dan tanggung jawab guruguru mata pelajaran dalam bimbingan dan konseling adalah:

a. Membantu memasyarakatkan pelayanan bimbingan dan konseling kepada siswa.

b. Membantu konselor mengidentifikasi siswa-siswa yang memerlukan layanan bimbingan dan konseling, serta pengumpulan data tentang siswa-siswa tersebut.

c. Mengalihtangankan siswa yang memerlukan pelayanan bimbingan dan konseling kepada konselor.

d. Menerima siswa alih tangan dari konselor, yaitu siswa yang menuntut konselor memerlukan pelayanan khusus, 


\section{GURU PROFESIONAL: Dalam Tugas Pokok dan Fungsi (Tupoksi)}

seperti pengajaran/latihan perbaikan, dan program pengayaan.

e. Membantu mengembangkan suasana kelas, hubungan guru-siswa dan hubungan siswa-siswayang menunjang pelaksanaan pelayanan pembimbingan dan konseling.

f. Memberikan kesempatan dan kemudahan kepada siswa yang memerlukan layanan atau kegiatan bimbingan dan konseling untuk mengikuti dan menjalani kegiatan yang dimaksudkan itu.

g. Berpartisipasi dalam kegiatan khusus penanganan masalah siswa, seperti konferensi kasus.

h. Membantu pengumpulan informasi yang diperlukan dalam rangka penilaian pelayanan bimbingan dan konseling serta upaya tindak lanjutnya.

Jika melihat realita bahwa di Indonesia jumlah tenaga konselor profesional memang masih relatif terbatas, maka peran guru sebagai pembimbing tampaknya menjadi penting. Ada atau tidak ada konselor profesional di sekolah, tentu upaya pembimbingan terhadap siswa mutlak diperlukan. Jika kebetulan di sekolah sudah tersedia tenaga konselor profesional, guru bisa bekerja sama dengan konselor bagaimana seharusnya membimbing siswa di sekolah. Namun jika belum, maka kegiatan pembimbingan siswa tampaknya akan bertumpu pada guru.

Berikut ini beberapa hal yang perlu diperhatikan bagi guru dalam mengoptimalkan perannya sebagai pembimbing:

1) Guru harus memiliki pemahaman tentang anak yang sedang dibimbingnya. Misalnya pemahaman tentang gaya dan kebiasaan belajar serta pemahaman tentang potensi dan bakat yang dimiliki anak, dan latar belakang kehidupannya. Pemahaman ini sangat penting, sebab akan menentukan teknik dan jenis bimbingan yang harus diberikan kepada mereka.

2) Guru dapat memperlakukan siswa sebagai individu yang unik dan memberikan kesempatan kepada siswa untuk belajar sesuai dengan keunikan yang dimilikinya.

3) Guru seharusnya nya dapat menjalin hubungan yang akrab, penuh kehangatan dan saling percaya, termasuk di dalamnya berusaha menjaga kerahasiaan 


\section{Syarifuddin}

data siswa yang dibimbingnya, apabila data itu bersifat pribadi.

4) Guru senantiasa memberikan kesempatan kepada siswanya untuk mengonsultasikan berbagi kesulitan yang dihadapi siswanya, baik ketika sedang berada di kelas maupun di luar kelas.

5) Guru sebaiknya dapat memahami prinsip-prinsip umum konseling dan menguasai teknik-teknik dasar konseling untuk kepentingan pembimbingan siswanya, khususnya ketika siswa mengalami kesulitan-kesulitan tertentu dalam belajarnya.

Sebagai pembimbing perjalanan, guru memerlukan kompetensi yang tinggi untuk melaksanakan empat hal berikut:

a) Guru harus merencanakan tujuan dan mengidentifikasi kompetensi yang hendak dicapai.

b) Guru harus melihat keterlibatan peserta didik dalam pembelajaran, dan yang paling penting bahwa peserta didik melaksanakan kegiatan belajar itu tidak hanya secara jasmaniah, tetapi mereka harus terlibat secara psikologis.

c) Guru harus memaknai kegiatan belajar.

d) Guru harus melaksanakan penilaian.

\section{Pelatih}

Guna menindaklanjuti Peraturan Menteri Pendidikan dan Kebudayaan No. 160 Tahun 2014 tentang Pemberlakuan Kurikulum 2006 dan Kurikulum 2013, pemerintah telah menerbitkan Peraturan Bersama Direktur Jenderal Pendidikan Dasar dan Direktur Jenderal Pendidikan Menengah Kementerian Pendidikan dan Kebudayaan No. 5496/C/KR/2014 dan No. 7915/D/KP/2014 tentang Petunjuk Teknis Pemberlakuan Kurikulum Tahun 2006 dan Kurikulum Tahun 2013 pada Sekolah Jenjang Pendidikan Dasar dan Pendidikan Menengah.

Yang menarik dari kehadiran Petunjuk Teknis (Juknis) ini, yaitu berkaitan dengan 'Model Pelatihan dan Pendampingan Kurikulum 2013'. Seperti diketahui, semula model Pelatihan dan Pendampingan Kurikulum 2013 yang digunakan adalah 'model berbasis guru' yang mengandalkan pada individu guru itu sendiri dengan mekanisme 'getok tular, dari satu mulut ke mulut lainnya'. Tetapi untuk ke depannya menurut Juknis ini, 


\section{GURU PROFESIONAL: Dalam Tugas Pokok dan Fungsi (Tupoksi)}

'Model Pelatihan dan Pendampingan Kurikulum 2013' yang akan digunakan adalah 'model berbasis satuan pendidikan' (Pasal 4 ayat 1).

Dalam pemahaman penulis, 'model pelatihan dan pendampingan berbasis satuan pendidikan' merupakan model dalam kegiatan pelatihan yang berlangsung di satuan pendidikan setempat (sekolah yang ditunjuk sebagai Sekolah Rintisan Penerapan Kurikulum 2013), dengan sasaran seluruh guru dan tenaga kependidikan yang ada di satuan pendidikan setempat. Seluruh guru sama-sama belajar tentang Kurikulum 2013 dan menerima materi pelatihan secara langsung dari sumber utama yang terpercaya, bukan dari sumber-sumber lain yang mungkin sudah jauh terdistorsi. Setiap guru di 'Sekolah Rintisan Penerapan Kurikulum 2013' dipantau dan dibimbing secara intensif tingkat kemampuannya dalam mengimplementasikan hasil pelatihan.

Demikian pula, dengan kepala sekolah, mereka akan mendapatkan pelatihan dan pendampingan secara intens dalam mengelola kurikulum 2013 dan mendapatkan bimbingan dari sumber yang terpercaya. Proses pendampingan dan setiap kegiatan pemecahan masalah (problem solving) benar-benar disesuaikan dengan karakteristik dan keunikan yang dimiliki masing-masing sekolah.

Guru harus berperan sebagai pelatih, yang bertugas untuk melatih peserta didik dalam pembentukan kompetensi dasar, sesuai dengan kompetensi masingmasing. Pelatihan yang dilakukan, di samping harus memperhatikan kompetensi dasar dan materi standar, juga harus mampu memperhatikan perbedaan individual peserta didik, dan lingkungannya. Untuk itu guru harus banyak tahu, meskipun tidak mencakup semua hal, dan tidak setiap hal secara sempurna, karena hal itu tidaklah mungkin.

\section{Penasihat}

Guru adalah seorang penasihat bagi peserta didik, bahkan bagi orang tua, meskipun mereka tidak memiliki latihan khusus sebagai penasihat dan dalam beberapa hal tidak dapat berharap untuk menasihati orang.

Dalam setiap langkah kehidupan, manusia tidak terlepas dari masalah karena masalah adalah bagian 


\section{Syarifuddin}

dari manusia yang hidup. Begitu pula halnya dengan peserta didik. Seringkali peserta didik mengalami kesulitan-kesulitan, seperti kesulitan belajar, kesulitan memecahkan masalah pribadi, kesulitan memecahkan masalah sosial, kesulitan mengambil keputusan, kesulitan menemukan jati diri, dan sebagainya. Kesulitan tersebut pasti akan mempengaruhi proses pembelajaran dan menentukan hasil dalam pencapaian tujuan.

Untuk itu seorang guru harus bertindak sebagai konsultan yang siap memberikan nasihat kepada peserta didik. Menjadi guru pada tingkat mana pun berarti menjadi penasihat dan menjadi orang kepercayaan, kegiatan pembelajaran pun meletakkannya pada posisi tersebut. Peserta didik senantiasa berhadapan dengan kebutuhan untuk membuat keputusan, dan dalam prosesnya akan lari kepada gurunya. Semakin guru itu kreatif, maka semakin efektif pula guru menangani setiap permasalahan, makin banyak kemungkinan peserta didik berpaling kepadanya untuk mendapatkan nasihat dan kepercayaan diri.

\section{Model atau Teladan}

Sejak zaman dahulu sampai sekarang, guru masih dianggap sebagai pekerjaan yang luhur, yang memiliki sifat dan karakter yang mulia yang dijadikan 'model' atau 'teladan' bagi masyarakat. Perhatian masyarakat terhadap guru begitu besar sehingga setiap apa yang terjadi dengan guru langsung dikomentari oleh masyarakat.

Perilaku guru di sekolah selalu menjadi figur dan dijadikan dalil bagi para siswanya untuk meniru perilaku tersebut. Hal ini wajar karena peserta didik dalam proses pembelajaran kadang melakukan modelinguntuk mengubah tingkah lakunya.

Sebagai teladan bagi peserta didik dan orang-orang di sekitarnya, mengharuskan guru melaksanakan kode etik keguruan yang menjadi dasar berperilaku, baik dalam interaksinya dengan Kepala Sekolah, teman sejawat, bawahan, peserta didik, dan masyarakat pada umumnya.

Guru merupakan model atau teladan bagi para peserta didik dan semua orang yang menganggap dia 


\section{GURU PROFESIONAL: Dalam Tugas Pokok dan Fungsi (Tupoksi)}

sebagai guru. Sebagai teladan, tentu saja pribadi dan apa yang dilakukan guru akan mendapat sorotan peserta didik serta orang di sekitar lingkungannya yang menganggap atau mengakuinya sebagai guru. Sehubungan itu, beberapa hal di bawah ini perlu mendapat perhatian, dan bila perlu didiskusikan para guru:
a. Sikap dasar
b. Bicara dan gaya bicara
c. Kebiasaan bekerja
d. Sikap melalui pengalaman dan kesalahan
e. Pakaian
f. Hubungan kemanusiaan
g. Proses berpikir
h. Selera
i. Keputusan
j. Kesehatan
k. Gaya hidup secara umum

\section{Pribadi}

Guru dituntut untuk memiliki kepribadian yang kukuh yang dapat dijadikan panutan bagi masyarakat. Segala tindak tanduknya selalu mendapat respons dari masyarakat. Karenanya nilai-nilai yang dijadikan prinsip hidupnya harus sejalan dengan nilai-nilai yang ada dalam masyarakat.

Guru sebagai pribadi harus memiliki nilai moral, kecerdasan intelektual, kecerdasan emosi, kecerdasan sosial, dan kecerdasan spiritual yang tinggi. Guru yang selalu bertutur kata kasar, tidak menghargai peserta didiknya serta terbiasa melakukan perbuatan-perbuatan yang tidak sepantasnya dilakukan oleh seorang pendidik, menunjukkan bahwa guru tersebut memiliki nilai moral yang kurang bagus, dan guru tersebut tidak pantas menjadi seorang pendidik yang baik.

Sebagai individuyangberkecimpungdalam pendidikan, guru harus memiliki kepribadian yang mencerminkan seorang pendidik. Tuntutan kepribadian sebagai pendidik kadang-kadang dirasakan lebih berat dibanding profesi lainnya. Ungkapan yang sering dikemukakan adalah bahwa 'guru bisa digugu dan ditiru'. Digugu maksudnya bahwa pesan-pesan yang disampaikan guru bisa dipercaya untuk dilaksanakan dan pola hidupnya bisa ditiru atau diteladani. Guru sering dijadikan panutan oleh masyarakat, 


\section{Syarifuddin}

untuk itu guru harus mengenal nilai-nilai yang dianut dan berkembang di masyarakat, tempat melaksanakan tugas dan bertempat tinggal.

\section{Peneliti}

Manusia adalah makhluk yang unik, satu sama lain berbeda. Manusia yang satu memiliki kelebihan yang tidak dimiliki oleh orang lain. Namun, mereka juga memiliki kelemahan yang tidak dimiliki yang lainnya. Demikian pula dengan peserta didik, mereka memiliki keunikan yang beraneka ragam dari waktu ke waktu. Karenanya guru tidak bisa memperlakukan mereka dengan cara yang sama untuk semua peserta didik dan untuk zaman yang berbeda. Hal ini menuntut guru mencari suatu sistem pembelajaran yang sesuai dengan perkembangan zaman dan tingkat perkembangan serta kebutuhan peserta didik tersebut.

Metode, strategi, media pengajaran yang diterapkan di suatu sekolah belum tentu cocok untuk sekolah yang lain. Begitu pula dengan perlakuan guru yang ditunjukkan di suatu daerah, belum tentu dapat diterima di daerah yang lain. Dengan demikian, apabila seorang guru ingin sukses menjadi 'guru yang profesional', hendaknya selalu mengadakan penyesuaian yang terlebih dahulu melakukan penelitian, untuk menghindari perlakuan yang salah dalam proses pembelajaran peserta didik.

Pembelajaran merupakan seni, yang dalam pelaksanaannya memerlukan penyesuaian-penyesuaian dengan kondisi lingkungan. Untuk itu, diperlukan berbagai penelitian, yang di dalamnya melibatkan guru. Oleh karena itu, guru adalah seorang pencari atau peneliti. Dia tidak tahu dan dia tahu bahwa dia tidak tahu, oleh karena itu dia sendiri merupakan subjek pembelajaran. Dengan kesadaran bahwa ia tidak mengetahui sesuatu maka ia berusaha mencarinya melalui kegiatan penelitian. Usaha mencari sesuatu itu adalah mencari kebenaran, seperti seorang ahli filsafat yang senantiasa mencari, menemukan dan mengemukakan kebenaran.

\section{Motivator}

Dalam proses pembelajaran peserta didik terkadang tidak memiliki motivasi belajar, apalagi menciptakan hal-hal baru yang dapat meningkatkan kompetensinya. 
Sebagai motivator, guru berkewajiban meningkatkan dorongan peserta didik untuk kreatif dalam belajar.

Motivasi merupakan salah satu faktor yang dapat meningkatkan kualitas pembelajaran, karena peserta didik akan sungguh-sungguh belajar apabila memiliki motivasi yang tinggi. Sebagai motivator, hendaknya guru memperhatikan prinsip-prinsip, sebagaimana yang dikatakan E. Mulyasa, berikut ini.
a. Peserta didik akan bekerja keras kalau memiliki minat dan perhatian terhadap pekerjaannya.
b. Memberikan tugas yang jelas dan dapat dimengerti.
c. Memberikan penghargaan terhadap hasil kerja dan prestasi peserta didik.
d. Menggunakan hadiah dan hukuman secara efektif dan tepat guna.
e. Memberikan penilaian dengan adil dan transparan.

Dalam upaya memberikan motivasi, guru dapat menganalisis motif-motif yang melatarbelakangi anak didik malas belajar dan menurun prestasinya di sekolah.

Motivasi dapat efektif bila dilakukan dengan memperhatikan kebutuhan anak didik penganekaragaman cara belajar memberikan penguatan dan sebagainya, juga dapat memberikan motivasi pada anak didik untuk lebih bergairah dalam belajar.

\section{Pendorong Kreativitas}

Sebagai orang yang kreatif, guru menyadari bahwa kreativitas merupakan yang universal dan oleh karenanya semua kegiatannya ditopang, dibimbing dan dibangkitkan oleh kesadaran itu, ia sendiri adalah seorang kreator dan motivator, yang berada di pusat proses pendidikan. Akibat dari fungsi ini, guru senantiasa berusaha untuk menemukan cara yang lebih baik dalam melayani peserta didik, sehingga peserta didik akan menilainya bahwa ia memang kreatif dan tidak melakukan sesuatu secara rutin saja. Kreativitas menunjukkan bahwa apa yang akan dikerjakan oleh guru sekarang lebih baik dari yang telah dikerjakan sebelumnya dan apa yang akan dikerjakan di masa mendatang lebih baik dari sekarang.

\section{Pembangkit Pandangan}




\section{Syarifuddin}

Dunia ini panggung sandiwara, yang penuh dengan berbagai kisah dan peristiwa, mulai dari kisah nyata sampai yang direkayasa. Dalam hal ini, guru dituntut untuk memberikan dan memelihara pandangan tentang keagungan kepada peserta didiknya.

Mengemban fungsi ini guru harus terampil dalam berkomunikasi dengan peserta didik di segala umur, sehingga setiap langkah dari proses pendidikan yang dikelolanya dilaksanakan untuk menunjang fungsi ini. Guru tahu bahwa ia tidak dapat membangkitkan pandangan tentang kebesaran kepada peserta didik jika ia sendiri tidak memilikinya. Oleh karena itu, para guru perlu dibekali dengan ajaran tentang hakikat manusia dan setelah mengenalnya akan mengenal pula kebesaran Allah yang menciptakannya.

\section{Pekerja Rutin}

Guru bekerja dengan keterampilan, dan kebiasaan tertentu, serta kegiatan rutin yang amat diperlukan dan seringkali memberatkan. Jika kegiatan tersebut tidak dikerjakan dengan baik, maka bisa mengurangi atau merusak keefektifan guru pada semua peranannya.

Sedikitnya terdapat 17 kegiatan rutin yang sering dikerjakan guru dalam pembelajaran di setiap tingkat, yaitu:

a. Bekerja tepat waktu baik di awal maupun akhir pembelajaran

b. Membuat catatan dan laporan sesuai dengan standar kinerja, ketepatan dan jadwal waktu

c. Membaca, mengevaluasi dan mengembalikan hasil kerja peserta didik

d. Mengatur kehadiran peserta didik dengan penuh tanggung jawab

e. Mengatur jadwal, kegiatan harian, mingguan, semesteran dan tahunan

f. Mengembangkan peraturan dan prosedur kegiatan kelompok, termasuk diskusi

g. Menetapkan jadwal peserta didik

h. Mengadakan pertemuan dengan orang tua dan dengan peserta didik

i. Mengatur tempat duduk peserta didik

j. Mencatat kehadiran peserta didik

k. Memahami peserta didik 


\section{GURU PROFESIONAL: Dalam Tugas Pokok dan Fungsi (Tupoksi)}

1. Menyiapkan bahan-bahan pembelajaran, kepustakaan, dan media pembelajaran

$\mathrm{m}$. Menghadiri pertemuan dengan guru, orang tua peserta didik dan alumni

n. Menciptakan ikhlas kelas yang kondusif

o. Melaksanakan latihan-latihan pembelajaran

p. Merencanakan program khusus dalam pembelajaran, misalnya karyawisata

q. Menasihati peserta didik.

\section{Seorang Aktor}

Sebagai seorang aktor, guru harus melakukan apa yang ada dalam naskah yang telah disusun dengan mempertimbangkan pesan yang akan disampaikan kepada penonton. Penampilan yang bagus dari seorang aktor akan mengakibatkan para penonton tertawa, mengikuti dengan sungguh-sungguh, dan bisa pula menangis terbawa oleh penampilan sang aktor.

Untuk bisa berperan sesuai dengan tuntutan naskah, dia harus menganalisis dan melihat kemampuannya sendiri, persiapannya, memperbaiki kelemahan, menyempurnakan aspek-aspek baru dari setiap penampilan, mempergunakan pakaian, tata rias sebagaimana yang diminta, dan kondisinya sendiri untuk menghadapi ketegangan emosinya dari malam ke malam serta mekanisme fisik yang harus ditampilkan

\section{Evaluator}

Evaluasi atau penilaian merupakan aspek pembelajaran yang paling kompleks, karena melibatkan banyak latar belakang banyak latar belakang dan hubungan, serta variabel lain yang mempunyai arti apabila berhubungan dengan konteks yang hampir tidak mungkin dapat dipisahkan dengan setiap segi penilaian, karena penilaian merupakan proses menetapkan kualitas hasil belajar, atau proses untuk menentukan tingkat pencapaian tujuan pembelajaran oleh peserta didik.

\section{Pengawet}

Salah satu tugas pendidikan adalah mewariskan kebudayaan dari generasi ke generasi berikutnya, karena hasil karya manusia terdahulu masih banyak yang bermakna bagi kehidupan manusia sekarang maupun di masa depan. Hal ini disebabkan oleh 


\section{Syarifuddin}

keberhasilan tugas pendidikan yang lain, yaitu pembekalan individu agar mampu berpartisipasi dalam masyarakat dan mampu memberikan sumbangan bagi kehidupan di masa depan. Upaya pelestarian dilakukan melalui pembekalan terhadap calon-calon guru.

Untuk melaksanakan tugasnya sebagai pengawet terhadap apa yang telah dicapai manusia terdahulu, dikembangkan salah satu sarana pendidikan yang disebut kurikulum, yang secara sederhana diartikan sebagai program pembelajaran

\section{Fasilitator}

Fasilitator, guru hendaknya dapat menyediakan fasilitas yang memungkinkan kemudahan kegiatan belajar anak didik. Lingkungan belajar yang tidak menyenangkan, suasana ruang kelas yang pengap, meja dan kursi yang berantakan, fasilitas belajar yang kurang tersedia, menyebabkan anak didik malas belajar. Oleh karena itu, menjadi tugas guru bagaimana menyediakan fasilitas, sehingga akan tercipta lingkungan belajar yang menyenangkan anak didik.

\section{Supervisor}

Guru hendaknya dapat membantu, memperbaiki, dan menilai secara kritis terhadap proses pengajaran. Teknik-teknik supervisi harus guru kuasai dengan baik agar dapat melakukan perbaikan terhadap situasi belajar mengajar menjadi lebih baik. Untuk itu kelebihan yang dimiliki supervisor bukan hanya karena pengalamannya, pendidikannya, kecakapannya, atau keterampilan-keterampilan yang dimilikinya, atau karena memiliki sifat-sifat kepribadian yang menonjol daripada orang-orang yang disupervisinya.

\section{B. Tugas Guru}

Guru adalah figur seorang pemimpin. Guru adalah sosok arsitektur yang dapat membentuk jiwa dan watak anak didik, guru mempunyai kekuasaan untuk membentuk dan membangun kepribadian anak didik menjadi seorang yang berguna bagi agama, nusa dan bangsa. Guru bertugas mempersiapkan manusia yang cakap yang dapat diharapkan membangun dirinya dan membangun bangsa dan Negara. 


\section{GURU PROFESIONAL: Dalam Tugas Pokok dan Fungsi (Tupoksi)}

Jabatan guru mempunyai banyak tugas, baik yang terkait dengan dinas ataupun diluar dinas dalam bentuk pengabdian. Imam Ghazali mengemukakan bahwa tugas pendidik adalah menyempurnakan, membersihkan, menyucikan, serta membawa hati manusia untuk taqarrub ilallāh, dengan, bahasa lain al-Nahlawi menyimpulkan tugas utama pendidik adalah tazkiyah al-nafs, yaitu mengembangkan, membersihkan, mengangkat jiwa peserta didik kepada Khaliq-Nya, menjauhkan dari kejahatan dan menjaganya agar tetap dalam fitrahnya yang hanīf.

Dalam Undang-Undang Guru dan Dosen disebutkan bahwa guru adalah pendidik profesional dengan tugas utama mendidik, mengajar, membimbing, mengarahkan, melatih, menilai dan mengevaluasi peserta didik pada pendidikan anak usia dini jalur pendidikan formal, pendidikan dasar dan menengah.

Adapun tugas pendidik secara umum adalah mendidik, dalam operasionalnya, mendidik adalah rangkaian proses mengajar, memberikan dorongan, memuji, memberi hadiah, membentuk contoh dan membiasakan. Sedangkan tugas khusus guru adalah:

1. Sebagai pengajar (Instruksional): Merencanakan program pengajaran dan melaksanakan program yang telah disusun dan penilaian setelah program itu dilaksanakan.

2. Sebagai pendidik (Edukator): Mengarahkan peserta didik pada tingkat kedewasaan yang berkepribadian sempurna.

3. Sebagai pemimpin (Manajerial): Memimpin dan mengendalikan diri sendiri, peserta didik dan masyarakat yang terkait, menyangkut upaya pengarahan, pengawasan, pengorganisasian, pengontrolan, partisipasi atas program yang dilakukan.

Di samping memiliki tugas utama sebagai pendidik, pengajar, pembimbing dan pelatih, maka tugas utama guru menurut Depdikbud merupakan tugas profesi. Yang harus dilaksanakan oleh seorang pendidik dalam rangka mengembangkan kepribadian, mengajar dalam rangka menyeimbangkan kemampuan berpikir, kecerdasan dan melatih dalam rangka membina keterampilan. Mendidik, mengajar dan melatih anak didik adalah tugas guru sebagai tugas profesional, yang dapat dirincikan sebagai berikut:

a. Tugas guru sebagai pendidik: Meneruskan dan mengembangkan ilmu pengetahuan dan teknologi 


\section{Syarifuddin}

kepada anak didik. Tugas guru sebagai pengajar: Meneruskan dan mengembangkan ilmu pengetahuan dan teknologi kepada anak didik.

b. Tugas guru sebagai pelatih: Menggabungkan keterampilan dan menerapkannya dalam kehidupan demi masa depan anak didik.

c. Tugas kemanusiaan. Membina anak didik dalam rangka meningkatkan dan mengembangkan martabat diri sendiri, kemampuan manusia yang optimal serta pribadi yang mandiri.

d. Tugas kemasyarakatan. Mengembangkan terbentuknya masyarakat Indonesia yang berdasarkan Pancasila dan UUD 1945.

Menurut Roesyyah N. K. yang dikutip oleh Djamarah, bahwa dalam mendidik anak didik, pendidik bertugas untuk:

1) Membentuk kepribadian anak didik yang harmonis, sesuai cita-cita dan dasar negara Pancasila.

2) Menyiapkan anak didik menjadi warga negara yang baik.

3) Sebagai perantara dalam belajar

4) Pendidik sebagai pembimbing untuk membawa anak didik ke arah kedewasaan.

5) Pendidik sebagai penghubung antara sekolah dan masyarakat

6) Pendidik sebagai penegak disiplin

7) Pendidik sebagai administrator dan manager

8) Pendidik sebagai suatu profesi

9) Pendidik sebagai perencana kurikulum

10) Sebagai pemimpin

11) Pendidik sebagai sponsor kegiatan anak-anak

Menurut Jamal Ma'mur Asmani dalam bukunya yang berjudul Tips Menjadi Guru Inspiratif, Kreatif, dan Inovatif memaparkan tugas-tugas guru:

a) Edukator (pendidik)

Tugas pertama guru adalah mendidik anak didik sesuai dengan materi pelajaran yang diberikan kepadanya. Sebagai edukator, ilmu adalah sangat utama. Membaca, menulis, berdiskusi, mengikuti informasi dan responsif terhadap masalah kekinian sangat menunjang peningkatan kualitas ilmu guru. 


\section{GURU PROFESIONAL: Dalam Tugas Pokok dan Fungsi (Tupoksi)}

b) Leader (pemimpin)

Guru juga sebagai pemimpin kelas, karena itu ia harus bisa menguasai, mengendalikan. Dan mengarahkan kelas menuju tercapainya tujuan pembelajaran yang berkualitas. Sebagai seorang pemimpin, guru harus terbuka, demokratis, egaliter, dan menghindari cara-cara kekerasan. Dan guru juga harus pandai membaca potensi anak didiknya yang beragam, dan mampu menggunakan multi pendekatan dalam mengajar demi menyesuaikan potensi dan spesifikasi yang beragam dari anak didiknya, serta memberikan saksi kepada anak didiknya yang melanggar aturan dengan tegas, adil, dan bijaksana.

c) Fasilitator

Guru bertugas memfasilitasi anak didik untuk menemukan dan mengembangkan bakatnya secara pesat. Menurut E. Mulyasa (2000), guru sebagai fasilitator sedikitnya harus memiliki 7 sikap seperti yang telah diidentifikasi Roger (dalam Knows, 1984) yaitu:

1. Tidak berlebihan mempertahankan pendapat dan keyakinannya atau kurang terbuka

2. Dapat lebih mendengarkan peserta didik, terutama tentang aspirasi dan perasaannya

3. Mau dan mampu menerima ide peserta didik yang inovatif, dan kreatif bahkan yang sulit sekalipun

4. Lebih meningkatkan perhatiannya terhadap hubungan dengan peserta didik seperti halnya terhadap bahan pembelajaran

5. Dapat menerima komentar balik (feedback), baik yang bersifat positif atau negatif, dan menerimanya sebagai pandangan yang konstruktif terhadap diri sendiri dan perilakunya

6. Toleran terhadap kesalahan yang dibuat peserta didik selama proses pembelajaran

7. Menghargai prestasi peserta didik, meskipun biasanya mereka sudah tahu prestasi yang dicapainya

d) Motivator

Seorang guru harus mampu membangkitkan semangat dan mengukur kelemahan anak didik 


\section{Syarifuddin}

bagaimanapun latar belakang hidup keluarganya, bagaimanapun kelam masa lalunya, dan bagai mana pun berat tantangannya

Menurut Oemar Hamalik (2008), memotivasi belajar penting artinya dalam proses belajar siswa, karena berfungsi mendorong, menggerakkan, dan mengarahkan kegiatan belajar siswa.

e) Administrator

Selain mendidik, guru harus dapat mengerjakan urusan tata usaha seperti membuat daftar induk, rapor, serta dapat mengoordinasi segala pekerjaan di sekolah secara demokratis

f) Evaluator

Dalam evaluasi ini, guru bisa memakai banyak cara, dengan merenungkan sendiri proses pembelajaran yang diterapkan, meneliti kelemahan dan kelebihan, atau dengan cara yang objektif, meminta pendapat orang lain, misalnya kepala sekolah, guru yang lain, dan murid-muridnya. 
GURU PROFESIONAL: Dalam Tugas Pokok dan Fungsi (Tupoksi)

\section{DAFTAR PUSTAKA}

E. Mulyasa, Menjadi Guru Professional, Bandung: PT. Remaja Rosdakarya, 2007.

Hamid Darmadi, Kemampuan Dasar Mengajar, Bandung: Alfabeta, 2009.

http:/ / pandidikan.blogspot.com/2010/05/peran-seorang guru.html/Tangsel,05/04/14/11:33AM.

Jamal Ma'ruf Asmani. Tips Menjadi Guru Inspiratif, Kreatif, dan Inovatif, Jogjakarta: Diva Press, 2009.

M. Suparta dan Herry Noer Aly, Metodologi Pengajaran Agama Islam, Jakarta: Amisco, 2008.

Ramayulis, Ilmu Pendidikan Islam, Jakarta: Kalam Mulia, t.th.

Syaiful Bahri Djamarah, Guru dan anak didik dalam interaksi edukatif, Jakarta: Rineka Cipta, 2005.

Syarifuddin Ridwan, Profesionalitas Guru, Tangsel: Namiya, 2012.

Undang-Undang Republik Indonesia Nomor 14 Tahun 2005 tentang Guru dan Dosen, Pasal 1 ayat (1). 